\title{
Sustainable Development vs. Post-Industrial Transformation: Possibilities for Russia
}

\author{
Sergey Zhironkin ${ }^{1,2 *}$, Magerram Gasanov ${ }^{2}$, Galina Barysheva², Eyvaz Gasanov ${ }^{3}$, Olga \\ Zhironkina $^{4}$, and Gennady Kayachev ${ }^{5}$ \\ ${ }^{1}$ T.F. Gorbachev Kuzbass State Technical University, Belovo Branch, 65264432 Ilyicha st., Inskoy, \\ Kemerovo oblast, Russia \\ ${ }^{2}$ National Research Tomsk Polytechnic University, Department of Economics, 634050, 30 Lenina st., \\ Tomsk, Russia \\ ${ }^{3}$ Khabarovsk State University of Economy and Law, Economics Department of International \\ Economic Relations Faculty, 680042134 Tikhookeanskaya st. Khabarovsk, Russia \\ ${ }^{4}$ Kemerovo institute (branch) of Plekhanov Russian University of Economics, Department of \\ Humanities, 650992, 39 Kuznetsky av., Kemerovo, Russia \\ ${ }^{5}$ Siberian Federal University, Department of Economy and Business Processes Management, 660041, \\ Krasnoyarsk, 79 Svobodny av.
}

\begin{abstract}
Today the theory of postindustrial society is one of the most widespread concepts which allow adequately comprehending the largescale changes that have occurred in the ecological consciousness of Western societies for the last thirty years. Offered in the late 1960s and early 1970 s by American and European researchers in the field of economics, social philosophy, and ecology, the integrated idea of sustainable development in postindustrial era incorporated the best elements of the scientific tradition dating back to the Age of Enlightenment. The article emphasizes that the key to modern social progress is the rapid technological development based on the transformation of science into a direct productive force. The measure of such progress is a shift from pure economic growth to the sustainable development. The authors describe the ways of changing Russian Government's attitude to economy regulation in postindustrial development to achieve the goals of sustainable development.
\end{abstract}

\section{Introduction}

Being a humanistic theory by its very nature, the concept of postindustrial society did not focus on the separation of opinions by economists and ecologists regarding the use of irreplaceable resources to ensure economic growth typical for almost the entire XX century. Assuming the possibility of convergence of two systems (economic and ecological), it was subjected to sharp criticism by orthodox economists of the market direction and anathematized by leading technocratic scientists.

\footnotetext{
* Corresponding author: zhironkin@inbox.ru
} 
In the 1990s, the most difficult and contradictory stage of recent Russian history, the fate of Russian interpretations of post-industrial theory also developed very dramatically. On the one hand, a significant number of economists and politicians who rejected the communist ideology declared themselves to be supporters of the neoliberal model of development, which became the basis of market transformations that have been carried out for the last decade [1-5]. Having put forward the thesis on the possibility of building a mediumdeveloped capitalist society in our country in a short time, they were objectively not interested in a detailed study of either postindustrial theory or the concept of sustainable development. The reason for this is the unequivocal conclusion that the start of sustainable development in Russia is not feasible, a country oriented to the primary sector of the economy and obviously far from the environmental standards of modern society. On the other hand, the researchers who have not changed their beliefs so radically have adopted the theory of sustainable development as an insignificantly modified doctrine of the postindustrial society and tried to hide behind their environmental rhetoric the desire to restore industry on the old technological basis, without deep technological modernization and changing the paradigm of accelerating economic growth to the ideas of sustainable development. It is understandable that in this case too, there can be no question of a deep penetration of the postindustrial concept into the internal logic of Russia's sustainable development.

\section{Materials and Methods}

The formula of Russian economy postindustrial development is concretized: neoindustrialization plus vertical integration [6-8]. This is the formula for the rise of the country to the state-corporate stage, to which the most developed industrial countries of the West and the East have now emerged. This is also the formula for entering a path of sustainable development, overcoming systemic and intermediate backwardness.

Solving development problems in accordance with this formula requires the implementation of a national program for the vertical integration of the economy, strengthening environmental responsibility of the state and corporations. The basis for this should be created by high-tech corporations with the government participation, which structure should be complemented by technologically breaking-through and rationally specialized production of the latest equipment capable of implementing technologies that have minimal impact on the environment.

Let's note the fundamental requirements from the part of sustainable development to the state-corporate economic system. It should ensure the neo-industrial transformation of Russia aimed at shaping the national technotronic productive forces, through the effect of vertical integration, the effect of macroeconomic planning, the organization of work on a "just in time" basis, the deep automatization and unmanned technologies embedding into agriculture, transport and mineral resources extracting. Considering vertical integration as a key possibility for improving the foundations of the state-and-corporate relations, the new type of macroeconomic planning should start without delay.

In the field of productive forces development, the new type of national macroeconomic planning should give the priority to the organization of technologically advanced production of microprocessors, robots and engines, which could significantly reduce mineral resources consumption and environmental damage in the form of emissions, air and water pollutions, including radioactive.

The key to success and neo-industrial creation is the curtailment of profit-taking from raw material extracting and semi-finished products for export with simultaneous deployment of effective state-and-corporate system of maximizing value added through the production of high-tech products of final demand.

In order to confidently enter the mainline of sustainable development, it is time for Russia to solve the fundamental issue of our era - the frivolous attitude of corporations to the 
negative impact on the environment, in accordance with the law of vertical integration, based on the economy of multi-industry corporations.

\section{Results and Discussion}

Barrier institutions and constraining factors of the structural and technological development of the Russian economy necessary for entering the path of sustainable development are technological multi-wayability, manifested in the functioning of the newest technological structures and relics. Its presence is due to the course of technological development evolution, the peculiarity of Russian Government structural and technological policy and the consequences of market transformations of the economy structure. The high level of fixed assets depreciation, the use of technologies of the third and fourth technological layers, lack of a developed industrial base capable of implementing environmental ideas and technological innovations, the lack of effective institutions conducive to the accelerated development of environmentally friendly technologies, characterized as the deindustrialization, are also limiting technological development.

The basic conditions for the sustainable development of Russia are structural modernization oriented institutional policy and its effective implementation, which has a key impact on the processes of technological and structural shifts and economy development as a whole, since it determines the level of transaction costs. An effective structuring mechanism in the formation of Russia's innovation economy is the clustering (network) structuring principle that ensures more effective implementation of competitive advantages and facilitates the replacement of the resource model, form the dissemination of new knowledge, technologies, innovations and network links between the cluster entities. However, the leading role in managing the processes of structural shifts is assigned to the state as a subject of budget investments and a generator of structural modernization.

The formation and functioning of a structural model meeting the requirements of sustainable development and the real needs of society require highly concentrated state structural policy mechanisms aimed at transforming the basic macroeconomic and sectoral proportions that contribute to overcoming the structural crisis and the sustainable innovation development of economy. In the conditions of financial and economic crisis, the NeoKeynesian models of social and economic development, based on the methodology of strengthening state regulation, acquired particular relevance, having caused some return to conservative models of economic policy. The use of the mechanism of state-and-private partnership is becoming more effective. Within this framework high-tech projects, joint venture funds, start-up companies, small satellite companies are financed. There is an urgent need for a significant expansion of the range of financial assistance to companies that minimize environmental damage through emitting government's guarantees to innovative companies, subsidizing part of their R\&D expenditures, granting them tax benefits and zero-interest loans, carrying out public purchasing of environmentally friendly products.

Practice clearly demonstrates the effect of such conformity: neo-industrial production of fixed assets is carried out by vertically integrated corporations. One naturally suggests another. Outside vertically integrated forms of business, technotronic production is not developed and does not work. And the turning point came in the mid-1970s, when inter-sectoral TNCs took command of the economy in the US, concentrating over $52 \%$ of total capital.

Vertical integration is a reproductive synthesis of science, mineral extracting and processing industries, with specialization in the production of specific types of finite scienceintensive products: microprocessors, computers, technotronic engines for various applications, aircraft, ships and ships, digital communications and digital television, household appliances, etc.

Let us list the essential features of vertical integration. 
The first of them is the inter-branch consolidation of industrial enterprises into a complete and unified cycle of reproduction of specific high-end products of final demand.

The second is guaranteed providing with the necessary material resources of postindustrial quality, starting from raw material redistribution, promotion from extraction minerals to their full processing and utilization of the waste products. In other words, the optimal consumption of the necessary material resources and the optimal proportion between extractive and processing operations are determined and maintained by the most vertically integrated structure.

The third is the target product specialization of a vertically integrated structure. It produces goods of technotronic quality, high-tech, capable of satisfying both intermediate and final demand, without increasing the load on the environment.

The fourth is the unification of technologically complementary extractive and processing industries, more precisely, the unification of manufacturing the means of production and production of end-use items. If a corporate structure needs new machine or assembly lines or modules, new laboratory or test equipment, it either produces it itself, or places orders on a competitive basis, or establishes the contractual relationship through the temporary and flexible connection of a particular production link, center, complex. All this makes it possible to use irreplaceable resources as new requests come from the market and, thus, reduce the overall mineral resource consumption.

The fifth is a flexible organizational structure, mobile in time and space. The corporation quickly gets rid of obsolete links, creates or adds new ones as it is developing, which ensures faster embedding of new technologies.

The sixth is the maintenance of relations between both direct (formal) and indirect (informal) economic dependences of key suppliers. So, it is not necessary to directly include a particular raw material enterprise in the formal structure of the corporation, so that it ensures a common end result.

The seventh is the concentration of industrial research in the structure of corporations and universities (academic science - outside of them). Today in Russia there is an opposite situation. The universities have largely lost their research base and reduced scientific staff. The former Soviet Union industrial science is scattered. Only in the defense industry the modern R\&D are still more or less preserved. As we see, there is no inter-branch corporations - no proper industrial research and development. A separate enterprise, outside the corporation, outside of vertical integration, cannot stimulate innovation activity from fundamental to applied researches. All this puts unavoidable barriers between the ideas of sustainable development in the post-industrial era and their implementation in Russian practice.

For a vertically integrated corporation, scientific and research activities become an internal factor. At the time, it was not in vain to argue about the nature of technological progress in relation to fixed assets investment: endogenous or exogenous. When in the 1950s the corporate form of industries only appeared and was still sporadic, such a question was topical. But now it is proved by the life itself, that the formation of a vertically integrated corporation as a universal form of industry organization in postindustrial era.

So, the vertical integration transforms the interdepartmental corporation into the main subject of postindustrial economy. The key criterion of the multi-industrial corporation, alas, is often underestimated: it unites technologically interconnected enterprises of several sectors of economy, i.e. production of final demand items and the means of production. It was in the inter-industry corporation where the practice found the main form of integration of two reproduction divisions: the production of materials and equipment, and the end-use goods.

Unfortunately, as evidenced from the concept of long-term development of the Russian economy until 2030, the government still does not expect the effect of vertical integration. 
However, without strengthening the effect of vertical integration, it is impossible to bring Russia to the trajectory of sustainable development, using the technological and logical breakthroughs of the emerging post-industrial world. Moreover, without vertical integration, the transition from raw material growth to an innovative type of development is certainly impossible. The goals outlined by the Russian government are simply unachievable with the preservation of the current economic system, the basis of which is oligarchic property, the dominance of raw material capital over technological and innovation, internal rupture of unified technological chains by redistribution. The processing industries have insufficient international competitiveness, because resources and semi-finished products are exported abroad. Existing corporations extract the maximum profit from the intermediate production, and this is why the manufacturing industry stays uncompetitive.

The transition from commodity growth to sustainable development, innovative diversification of the economy, the widespread lean production implementing in key sectors of the economy by 2020 , are the interlinked benchmarks. The system of raw material oligarchy must be transformed into high-tech lobbyism, and as soon as possible. It is vertical integration with its postindustrial organizational and economic mechanisms that puts an end to the whole system of extraction profits from raw-materials and intermediate production. With vertical integration, the state no longer has to pedal the administrative, tax, customs, tariff and other methods of allocating resources between domestic and foreign markets. Multisectoral corporations, in which the intermediate and final productions are integrated, will maximize corporate profits, thereby increasing the output of final demand goods.

The practical solution is unique: the urgent integration of raw material and processing sectors of economy with the primacy of the latest one. Therefore, the process of integration of technologies, labor and capital of both sectors should be initiated and carried out by the state.

\section{Conclusion}

Thus, entering of Russian economy the way of sustainable development is possible when a set of dominant problems of postindustrial structure changes in productive forces and institutions is solved; when a combination of direct, indicative impact and market selfregulation are taken into account; when the strategic planning and targeted programming of mutual economic and ecological development are fulfilled. Therefore, it is necessary to study further the content, trends, instruments and institutions of the postindustrial transformation of the structure of Russian economy as a key to the sustainable development.

\section{References}

1. A. Auzan, Economics of everything. How the institutes define our life (Moscow, Mann, 2013)

2. G.A. Barysheva, E.G. Novoselova, App. Mech. Mater. 682, 550-554 (2014)

3. S. Glaziev, Rus. Econ. J., 2, 3-6. (2012)

4. I. Kurnysheva, S. Lykov, A. Idrisov, Economist, 10, 39-47 (2008)

5. V. Volchik, Institution and evolution economy (Rostov, UFU, 2011)

6. S. Zhironkin, V. Guzyr, Eur. Proc. Soc. Beh. Sci. VII, 160-166 (2016)

7. S. Zhironkin, M. Gasanov, O. Zhironkina, Eur. Proc. Soc. Beh. Sci. VII, 124-131 (2016)

8. E.A. Gasanov, N.V. Gasanova, A.V. Zhavoronok, Eur. Proc. Soc. Beh. Sci. Eur. Proc. Soc. Beh. Sci. VII, 323-336 (2016) 
